\title{
DNA synthesis by ovine mammary alveolar epithelial cells: effects of heparin, epidermal growth factor-related peptides and interaction with stage of pregnancy
}

\author{
I A Forsyth, J A Taylor and C D Moorby \\ Department of Cellular Physiology, The Babraham Institute, Babraham, Cambridge CB2 4AT, UK \\ (Requests for offprints should be addressed to I A Forsyth) \\ (C D Moorby is now at MRC Centre for Mechanisms in Human Toxicity, Hodgkin Building, Leicester University, Lancaster Road, Leicester LE1 6HN, UK)
}

\begin{abstract}
Amphiregulin is a heparin-binding member of the epidermal growth factor (EGF) family, which we have recently shown to be expressed in sheep mammary gland. Uniquely among known EGF-like growth factors, its mitogenic activity is inhibited by soluble heparin, but heparin-like molecules on the cell surface and/or in extracellular matrix appear to be necessary for amphiregulin to exert its biological effect. In primary cultures of sheep mammary alveolar epithelial cells, heparin (1-20 mg/l) inhibited DNA synthesis in a dose-dependent manner. The extent of the inhibition was influenced by physiological state, being greater $(P<0.05)$ in mammary cell cultures derived from 5- to 10-week pregnant sheep $(63 \cdot 1 \pm 8 \cdot 2 \%$, mean \pm S.E.M., $n=8)$ than in cultures derived from sheep which were non-pregnant $(35 \cdot 8 \pm 8 \cdot 3 \%$ inhibition, $n=6)$ or late, 20 -week, pregnant $(39 \cdot 8 \pm 5 \cdot 6 \%$,
\end{abstract}

$n=6)$. Both EGF and transforming growth factor- $\alpha$ (TGF- $\alpha)$ significantly $(P<0 \cdot 001)$ increased DNA synthesis in the presence of heparin. The effect of TGF- $\alpha$ was dose-related, wholly reversing the inhibitory effect of heparin in cell cultures from non-pregnant and 20-week pregnant sheep. DNA synthesis was stimulated by amphiregulin and TGF- $\alpha$ increased the maximum response. The heparin antagonist, hexadimethrine, inhibited DNA synthesis, but, in the presence of amphiregulin, approximately equivalent concentrations of heparin overcame this inhibitory effect. In the presence of heparin, TGF- $\alpha$ showed synergistic interactions with insulin or IGF-I. The results indicate interactive effects of EGF and IGF growth factor families in sheep mammary growth.

Journal of Endocrinology (1998) 156, 283-290

\section{Introduction}

Endocrine control of postnatal mammary gland growth is now known to involve the mediation of locally-produced growth factors, acting as autocrine, juxtacrine and paracrine regulators of cell proliferation. An increasing number of growth factors produced by and acting on mammary cells is being identified and an understanding of how these endogenous factors may interact becomes important. Synthesis of DNA in sheep mammary epithelial cells is stimulated by insulin-like growth factor (IGF) (Winder et al. 1989) and by transforming growth factor- $\alpha$ (TGF- $\alpha$ ) (Moorby et al. 1995). We now investigate amphiregulin, another member of the epidermal growth factor (EGF) family expressed in the normal sheep mammary gland (Forsyth et al. 1997), and interaction among the IGF and EGF growth factor families. A preliminary report has been made of some of this work (Forsyth \& Moorby 1993).

Amphiregulin, a glycoprotein of 84 amino acids, or 78 in a truncated form, is derived from a 252 amino acid transmembrane precursor. Amphiregulin was originally isolated by Shoyab et al. $(1988,1989)$ from medium conditioned by the MCF-7 human mammary carcinoma cell line, treated with a phorbol ester. It is expressed in normal mammary gland of man (four strains of normal passaged cells, Li et al. 1992, nontransformed, immortalized cells, Kenney et al. 1993), mouse (Kenney et al. 1995) and sheep (Forsyth et al. 1997), as well as in human ovary, placenta (Plowman et al. 1990, Johnson et al. 1991) and keratinocytes (Cook et al. 1991).

Amphiregulin shares with EGF and TGF- $\alpha$ the ability to interact with the EGF (ErbB-1) receptor (Shoyab et al. 1989). Unlike EGF and TGF- $\alpha$, amphiregulin binds heparin, a property conferred by a highly basic 40 amino acid N-terminal extension (Thorne \& Plowman 1994). Several studies show that soluble heparin and other sulphated glycosaminoglycans attenuate amphiregulindependent mitotic activity in keratinocytes (Cook et al. 1991, Piepkorn et al. 1994) and in human mammary epithelial cells (Li et al. 1992). It is thought that this results from prevention of the interaction of amphiregulin with high-affinity EGF receptors. By contrast, the biological 
activity of other members of the EGF family is either unaffected (EGF and TGF- $\alpha$ ) or enhanced (heparinbinding EGF, Cook et al. 1995a) by heparin. Nevertheless, further studies indicate that extracellular heparan sulphate glycosaminoglycans are necessary for amphiregulin mitogenic signalling in MCF-10A cells (Johnson \& Wong 1994) and keratinocyte cell lines (Cook et al. 1995b). By using heparin and the heparin antagonist, hexadimethrine (Kimura et al. 1959) in primary cultures, we have attempted to assess the physiological significance of endogenous amphiregulin in stimulating DNA synthesis in sheep mammary gland and to study interaction among members of the EGF and IGF growth factor families.

\section{Materials and Methods}

\section{Materials}

Human TGF- $\alpha$, human EGF and human IGF-I are recombinant peptides, purchased from Bachem (UK) Ltd (Saffron Walden, Essex, UK). Recombinant human amphiregulin was from R\&D Systems Europe (Abingdon, Oxon, UK). Sigma (Poole, Dorset, UK) supplied bovine insulin, heparin (tissue culture tested) from porcine intestinal mucosa, hexadimethrine bromide and powdered Medium 199, with Earle's salts and without phenol red. Medium 199 was prepared in double-distilled water and supplemented with Hepes $(25 \mathrm{mmol} / \mathrm{l})$, L-glutamine $(0.68 \mathrm{mmol} / \mathrm{l})$, anhydrous sodium acetate $(5 \mathrm{mmol} / \mathrm{l})$, sodium bicarbonate $(1 \cdot 1 \mathrm{~g} / \mathrm{l})$, BSA fraction $\mathrm{V}(5 \mathrm{~g} / \mathrm{l})$, kanamycin monosulphate $(128 \mathrm{mg} / \mathrm{l})$ and gentamycin sulphate $(10 \mathrm{mg} / \mathrm{l})$ as described by Moorby et al. (1995). [Methyl- ${ }^{3} \mathrm{H}$ ] Thymidine $(185 \mathrm{GBq} / \mathrm{mmol})$ and $\left(\left[{ }^{125} \mathrm{I}\right]\right.$ iodotyrosyl) TGF- $\alpha$ (human recombinant) were from Amersham International plc (Little Chalfont, Bucks, UK). Hexadimethrine is a polymeric polycation (polybrene) found to neutralize the effects of heparin in vivo and in vitro (Kimura et al. 1959). It inhibits the mitogenic effects of amphiregulin on keratinocytes, without any apparent toxic effects (Cook et al. 1995b).

\section{Animals}

Welsh Mountain ewes were kept under standard husbandry conditions. They were non-pregnant, 5-, 10-, 15or 20-weeks pregnant (average pregnancy about 22 weeks) or had suckled lambs for 10 weeks. Sheep were killed by an intravenous overdose of Lethobarb (Duphar, Southampton, Hants, UK). Udder tissue was immediately removed under sterile conditions and used for isolation by collagenase/hyaluronidase digestion of clumps of mammary epithelial cells (Winder et al. 1992).

\section{Cell culture}

Ovine alveolar mammary epithelial cells were cultured under serum-free conditions on gels of rat tail collagen as described by Winder et al. (1992). Cell clumps attached overnight to the collagen in the presence of fibronectin (Sigma, $4 \mu \mathrm{g} / \mathrm{ml}$ ). Treatments, replicated 3 or 4 times, began on the following day and the medium was changed every $24 \mathrm{~h}$. Cultures were terminated at subconfluence to avoid detachment of gels (Winder et al. 1992). This was on day 3 for cultures from 15- to 20-week pregnant sheep and days 4-5 for other stages. Synthesis of DNA was determined by incorporation of $\left[{ }^{3} \mathrm{H}\right]$ methyl thymidine added for the last $24 \mathrm{~h}$ of culture (Winder et al. 1989). Concentration of DNA was measured using $4 \%$ (w/v) 3,-5-diaminobenzoic acid (Hinegardner 1971) and results expressed as d.p.m./ $\mu$ g DNA. Unless stated otherwise, $n=$ number of independent experiments each carried out on cells prepared from a different sheep. To reduce the resulting variance, some data have been normalised by expression as percentage of DNA synthesis by cells cultured in medium only, or were $\log _{10}$ transformed for analysis (Tables 1 and 2).

\section{Binding of TGF-a to mammary microsomes}

Microsomes prepared from mammary tissue of nonpregnant, pregnant and lactating sheep were pooled as described by Moorby et al. (1995). Binding assays were carried out in triplicate by the method of Moorby et al. (1995) using the pooled microsomes at $300 \mu \mathrm{g}$ protein per tube and 20000 c.p.m. ${ }^{125}$ I-labelled TGF- $\alpha$ in a total volume of $400 \mu \mathrm{l}$. Heparin was added at $0,0 \cdot 1,0 \cdot 5,1 \cdot 0$, 1.5 and $2.0 \mu \mathrm{g} /$ tube.

\section{Statistical analysis}

The significance of differences in response was tested either by Student's $t$-test or by analysis of variance (ANOVA).

\section{Results}

\section{Effect of heparin on DNA synthesis}

Heparin inhibits EGF-independent growth of human mammary epithelial cells, an effect attributed to prevention of interaction between endogenous amphiregulin and the EGF receptor ( $\mathrm{Li}$ et al. 1992). Heparin (1-20 mg/l) similarly inhibited DNA synthesis by sheep mammary alveolar epithelial cells in serum and growth factorfree medium, with a maximum effect at $5-10 \mathrm{mg} / \mathrm{l}$ (Fig. 1). The amount of DNA per well was reduced from $0 \cdot 86 \pm 0 \cdot 14 \mu \mathrm{g} /$ well (mean \pm s.E.M.) in medium to $0.53 \pm 0.08 \mu \mathrm{g} /$ well $(n=29, P<0 \cdot 001$, paired Student's $t$-test).

If heparin inhibition reflects a role for endogenous amphiregulin in mammary growth, then the greatest effect may be expected in cells derived from pregnant sheep. In 


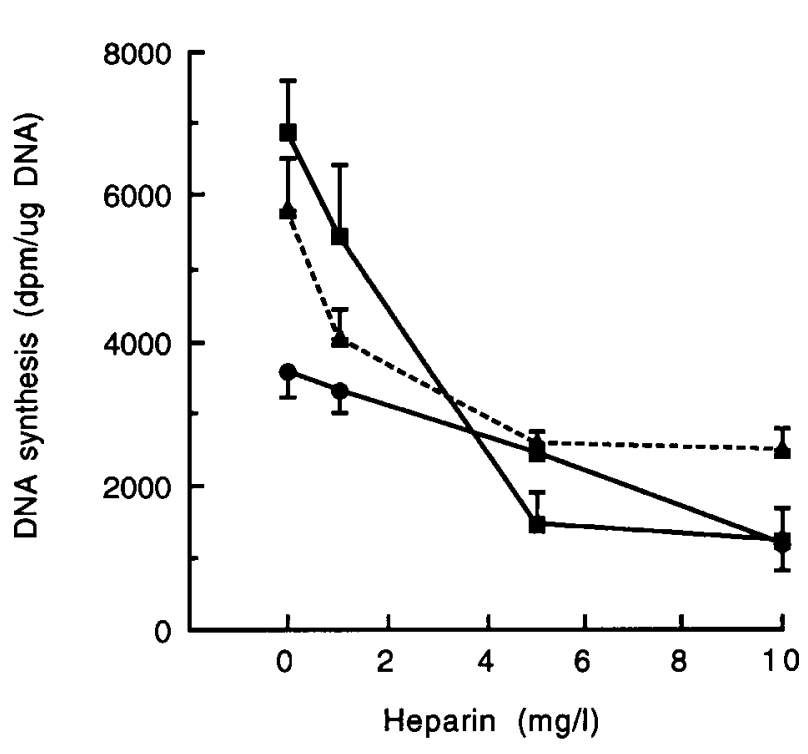

Figure 1 Effect of heparin on DNA synthesis $\left(\left[{ }^{3} \mathrm{H}\right]\right.$ methyl thymidine incorporation, d.p.m./ $\mu$ g DNA) by sheep mammary alveolar epithelial cells grown on collagen gels. Cells were prepared from a non-pregnant $(\mathbf{O})$, 5-week pregnant $(\boldsymbol{\square})$ or 20 -week pregnant $(\boldsymbol{\Delta})$ sheep. Values are means \pm S.E.M. of four replicates.

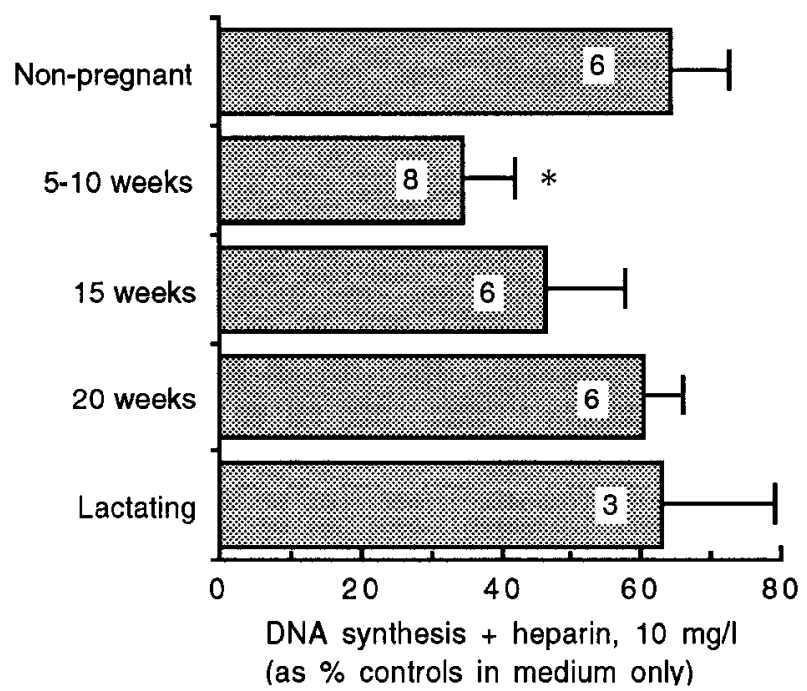

Figure 2 Effect of physiological state on the response of DNA synthesis to heparin $(10 \mathrm{mg} / \mathrm{l})$ in cultured sheep mammary alveolar epithelial cells. Values (means+S.E.M.) are DNA synthesis (\%) compared with control cultures without heparin. The number of sheep contributing to each observation is shown within each bar. ${ }^{*} P<0.05$ compared with non-pregnant and 20 -week pregnant sheep.

mammary cells from sheep 5- to 10-weeks pregnant, DNA synthesis was reduced to $35 \%$ of control values (Fig. 2; 65\% inhibition). This was significantly $(P<0 \cdot 05$, Student's $t$-test) different from the reduction to about $60 \%$ of control (40\% inhibition) when cells were derived from non-pregnant or late, 20-week, pregnant sheep. In mammary cells from 15-week pregnant sheep, the effect of heparin was intermediate. Cells from lactating sheep behaved similarly to those from non-pregnant sheep.

\section{Effects of TGF- $a$ or EGF on heparin inhibition}

We have previously shown that TGF- $\alpha$ approximately doubles DNA synthesis by sheep mammary epithelial cells. EGF displaces ${ }^{125}$ I-TGF- $\alpha$ from sheep mammary microsomes, but shows no consistent effect on DNA synthesis (Moorby et al. 1995). As heparin does not inhibit the biological activity of TGF- $\alpha$ or of EGF (Cook et al. 1995b), their ability to reverse the inhibitory effect of heparin on DNA synthesis was tested.

Heparin was first shown to have no effect on binding of TGF- $\alpha$ to pooled sheep mammary microsomes. Binding of ${ }^{125}$ I-labelled TGF- $\alpha$ was $9 \cdot 6 \%$. On addition of heparin, $0 \cdot 1,0 \cdot 5,1 \cdot 0,1 \cdot 5$ or $2 \mu \mathrm{g} /$ tube, (final concentration $0 \cdot 25$ $5 \mathrm{mg} / \mathrm{l}$ ), binding was $9 \cdot 3,9 \cdot 6,10 \cdot 0,9 \cdot 8$ and $9 \cdot 4 \%$ respectively. The effect of TGF- $\alpha(0 \cdot 1,1 \cdot 0,10$ or $100 \mu \mathrm{g} / \mathrm{l})$ or EGF $(1,10$ and $100 \mu \mathrm{g} / \mathrm{l})$ on DNA synthesis was tested in the presence and absence of heparin $(10 \mathrm{mg} / \mathrm{l})$ in mammary cells derived from sheep ( $n=5$ at each stage) which were non-pregnant, 10-, 15- or 20-weeks pregnant (Tables 1 and 2). Heparin significantly $(P<0 \cdot 001)$ inhibited DNA synthesis and there were significant interactions of pregnancy stage with heparin treatment (see also Fig. 2). There was a significant $(P<0 \cdot 001)$ dose-related effect of TGF- $\alpha$ on DNA synthesis in both the presence and absence of heparin, but there was no interaction between pregnancy stage and response to TGF- $\alpha$, in confirmation of previous results (Moorby et al. 1995). At $10 \mu \mathrm{g} / 1$ (Fig. 3) and $100 \mu \mathrm{g} / \mathrm{l}$, TGF- $\alpha$ was able completely to overcome the inhibitory effect of heparin in cells from non-pregnant and 20 -week pregnant ewes.

EGF significantly increased DNA synthesis in the presence and absence of heparin (Table 2, P<0.001), but the effect was smaller and not clearly dose-related compared with TGF- $\alpha$.

\section{Effect of amphiregulin and interaction with TGF-a}

To determine if amphiregulin is a sheep mammary gland mitogen, its effect on DNA synthesis was tested in epithelial cells from 20 -week pregnant sheep. TGF- $\alpha$ was more potent (Fig. 4a), but maximum DNA synthesis was the same in response to TGF- $\alpha$ and to amphiregulin. Surprisingly, a maximally effective dose of TGF- $\alpha(10 \mu \mathrm{g} / \mathrm{l})$ significantly $(P<0 \cdot 02$, paired Student's $t$-test $)$ increased the response to amphiregulin $(1 \mathrm{mg} / \mathrm{l})(4330 \pm 323$ vs $8224 \pm 842$ d.p.m./ $\mu$ g DNA, $n=4)$.

\section{Effects of hexadimethrine}

The heparin antagonist, hexadimethrine, is selective in its effects on the mitogenic activity of EGF-related growth 
Table 1 Effect of TGF- $\alpha$ on the synthesis of DNA by sheep mammary alveolar cells without ( - ) or with $(+)$ heparin $(10$ mg/l). Results (means) are shown (upper panel) normalized as \% of control DNA synthesis by cells in medium only. Control DNA synthesis (d.p.m./ $\mu \mathrm{g}$ DNA, mean \pm S.E.M.) at 0, 10, 15 and 20 weeks of pregnancy was $18913 \pm 12$ 161, 1552 $\pm 426,5318 \pm 2302$ and $8504 \pm 3986$ respectively. Cells derived from five sheep were studied at each stage of pregnancy. The significance of differences was calculated (lower panel) by ANOVA using values for DNA synthesis expressed as d.p.m./ $/ \mathrm{g}$ DNA, and $\log _{10}$ transformed to reduce variance

\begin{tabular}{|c|c|c|}
\hline & \multicolumn{2}{|c|}{ Stages of pregnancy (weeks) } \\
\hline & \multicolumn{2}{|l|}{0} \\
\hline & - & + \\
\hline \multicolumn{3}{|l|}{ Dose of TGF- $\alpha(\mu \mathrm{g} / \mathrm{l})$} \\
\hline 0 & 100 & $69 \cdot 8$ \\
\hline $0 \cdot 1$ & $118 \cdot 3$ & $78 \cdot 6$ \\
\hline $1 \cdot 0$ & $133 \cdot 8$ & $121 \cdot 9$ \\
\hline 10 & $154 \cdot 7$ & $132 \cdot 7$ \\
\hline \multirow[t]{2}{*}{100} & $168 \cdot 1$ & $155 \cdot 6$ \\
\hline & $\begin{array}{l}\text { Degrees of } \\
\text { freedom }\end{array}$ & $P$ value \\
\hline \multicolumn{3}{|l|}{ Source of variation } \\
\hline Dose of TGF- $\alpha$ & 4 & $<0 \cdot 001$ \\
\hline Stage of pregnancy & 3 & $<0.05$ \\
\hline Heparin & 1 & $<0.001$ \\
\hline Dose $\times$ stage & 12 & $>0 \cdot 1$ \\
\hline Stage $\times$ heparin & 3 & $<0 \cdot 001$ \\
\hline
\end{tabular}

Table 2 Effect of EGF on the synthesis of DNA by sheep mammary alveolar cells without ( - ) or with $(+)$ heparin $(10 \mathrm{mg} / \mathrm{l})$. Results (means) are shown (upper panel) normalized as \% of control DNA synthesis by cells in medium only. For values at $100 \%$, see Table 1. Cells derived from five sheep were studied at each stage of pregnancy. The significance of differences was calculated (lower panel) by ANOVA using values for DNA synthesis expressed as d.p.m./ $\mu \mathrm{g}$ DNA, and $\log _{10}$ transformed to reduce variance

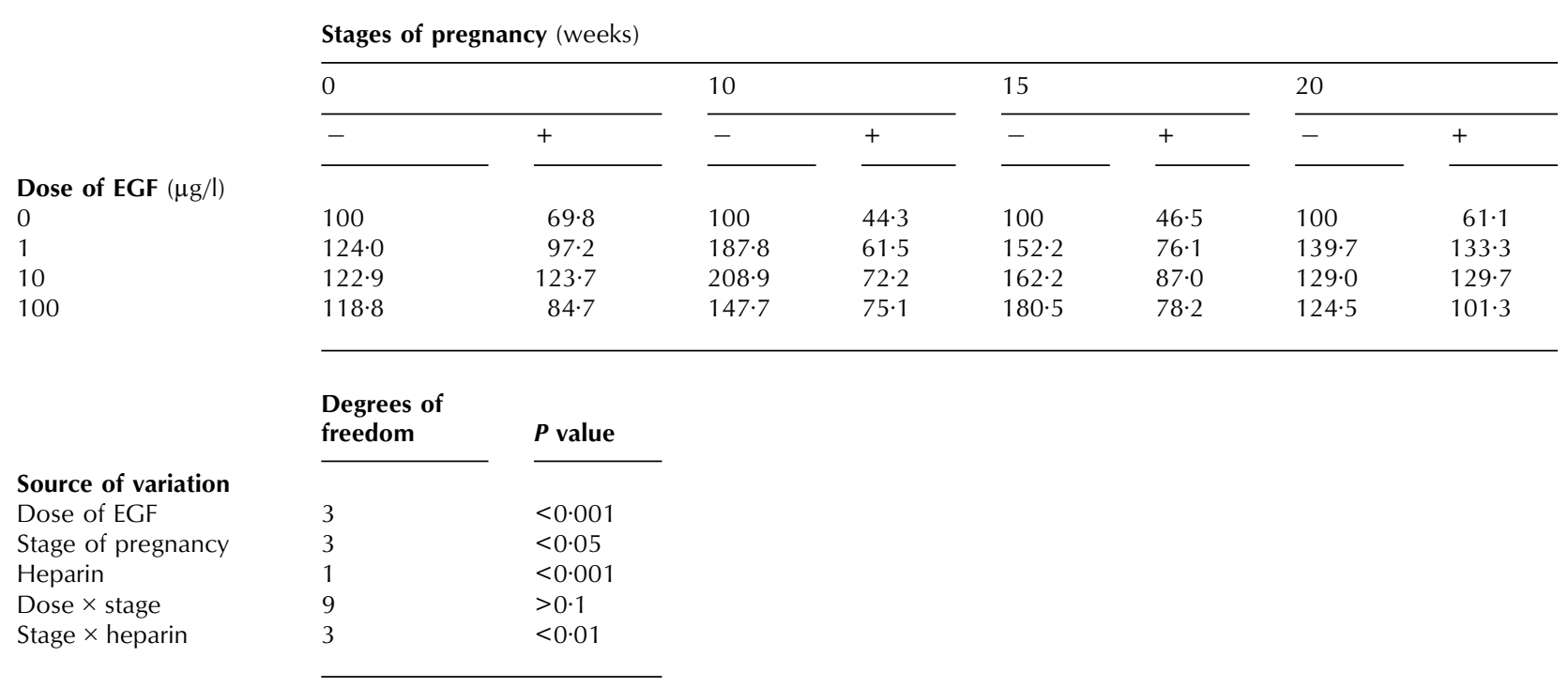

factors, inhibiting amphiregulin-induced DNA synthesis by keratinocytes, but enhancing or having no effect on the activity of EGF (Cook et al. 1995b). The suggested mechanism is disruption of interaction between amphiregulin and cell surface sulphated proteoglycans. In alveolar epithelial cells from 20-week pregnant sheep, hexadimethrine was inhibitory at doses of $1 \mathrm{mg} / 1(57 \cdot 5 \pm 0 \cdot 6 \%$ of DNA synthesis in medium only, mean \pm s.E.M., $n=3)$ and $10 \mathrm{mg} / 1(22 \cdot 7 \pm 5 \cdot 2 \%)$ in the presence of amphiregulin $(500 \mu \mathrm{g} / 1, P<0 \cdot 01$, paired Student's $t$-test). Similar inhibition was obtained in basal medium $(51 \cdot 3 \%$ and $21 \cdot 2 \%$ respectively). Heparin was able to reverse the inhibitory 


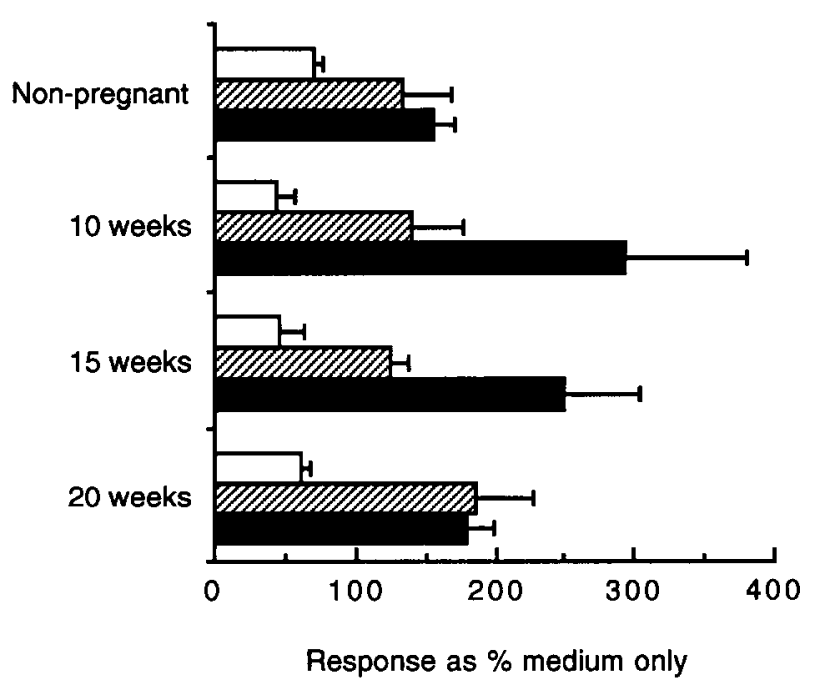

Figure 3 Effects of heparin (10 mg/l, open bars), heparin+TGF- $\alpha$ $(10 \mu \mathrm{g} / \mathrm{l}$, hatched bars) and TGF- $\alpha$ (solid bars) on DNA synthesis by cultured mammary alveolar epithelial cells from sheep which were non-pregnant or 10-, 15- or 20-weeks pregnant. Values are means+S.E.M. for cells from five sheep, expressed as a percentage of $\left[{ }^{3} \mathrm{H}\right]$ methyl thymidine incorporation by cells cultured in medium only in each experiment.

effect of hexadimethrine on amphiregulin-stimulated DNA synthesis, although heparin became inhibitory again when present in excess (Fig. 5).

Effect of TGF-a on the response of DNA synthesis to insulin or IGF-I: influence of heparin

The dose-dependent effect of both insulin (Fig. 4b) and IGF-I (Moorby et al. 1995) is enhanced by TGF- $\alpha$. Cultures were carried out in the absence and presence of heparin to test statistically whether these interactions are additive or synergistic, using maximally effective doses of TGF- $\alpha(10 \mu \mathrm{g} / \mathrm{l})$, insulin $(100 \mu \mathrm{g} / \mathrm{l})$ and IGF-I $(10 \mu \mathrm{g} / \mathrm{l})$. The ratio was calculated: (response to insulin or IGF-I in the presence of TGF- $\alpha$ ) to (response to insulin or IGF-I plus response to TGF- $\alpha$ ) (Moorby et al. 1995). The ratio was corrected for the double contribution of basal incorporation in the denominator, using experimentally determined values in the presence or absence of heparin in each culture. A ratio greater than 1.0 indicates a synergistic interaction. The results are shown in Fig. $6 a$ (insulin) and $6 b$ (IGF-I). The ratio is significantly affected by heparin $(P<0 \cdot 05$, ANOVA) for both the interaction between insulin and TGF- $\alpha$ and IGF-I and TGF- $\alpha$. The effect of pregnancy stage was not significant, but the highest mean ratios were in tissue from 10-week pregnant sheep in the presence of heparin (4.45 for insulin and 3.02 for IGF-I, Fig. $6 a, b)$.

The overall mean ratios for interaction of insulin and TGF- $\alpha$ were $1.44 \pm 0.64$ (s.D.) in the absence and

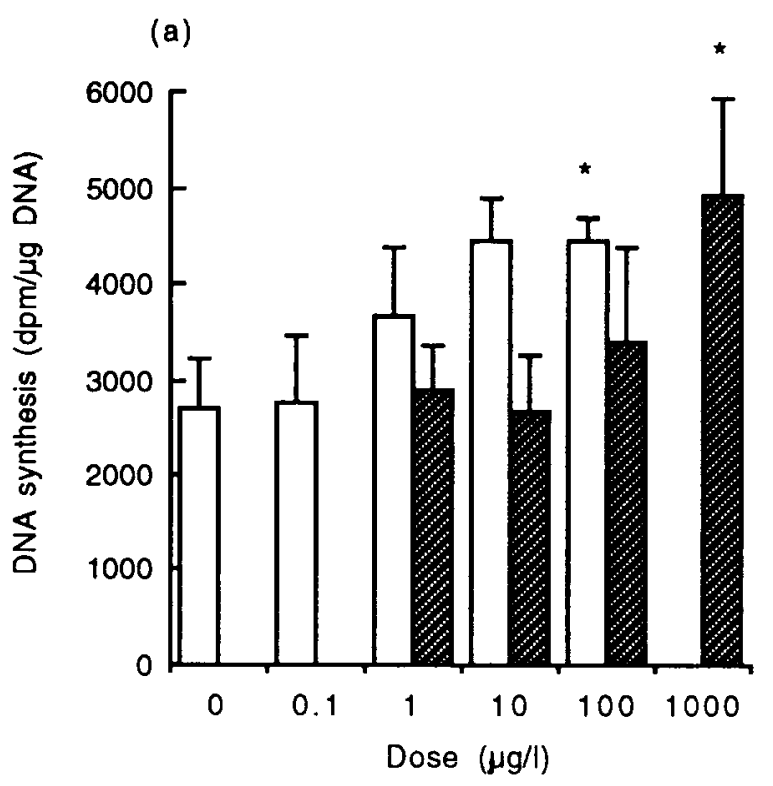

(b)

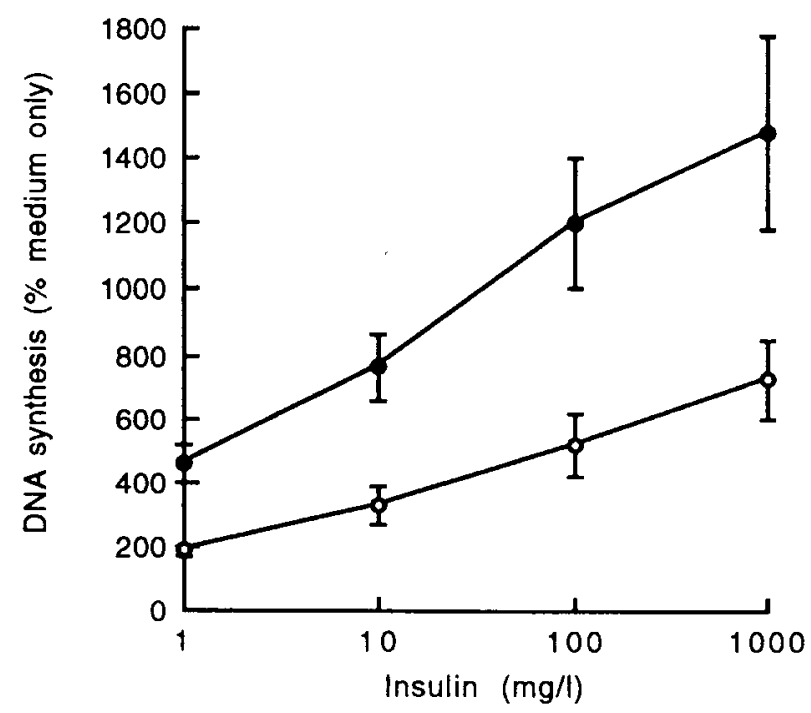

Figure 4 Response of DNA synthesis to (a) TGF- $\alpha$ (open bars) or amphiregulin (hatched bars), $n=3$, and (b) insulin (O) or insulin+ TGF- $\alpha(\bullet, 10 \mu \mathrm{g} / \mathrm{l}), n=6$, in mammary alveolar epithelial cells from 15- to 20-week pregnant sheep. Values are means \pm S.E.M. ${ }^{*} P<0.05$ compared with medium only.

$2 \cdot 96 \pm 2.94$ in the presence of heparin, both significantly different from $1 \cdot 0(P<0 \cdot 01$, degrees of freedom 18). For interaction of IGF-I and TGF- $\alpha$, the ratios were $1 \cdot 15 \pm 0.56(P>0 \cdot 1$, degrees of freedom 19) without heparin and $2 \cdot 09 \pm 1 \cdot 80(P<0 \cdot 02$, degrees of freedom 19) in the presence of heparin respectively. 

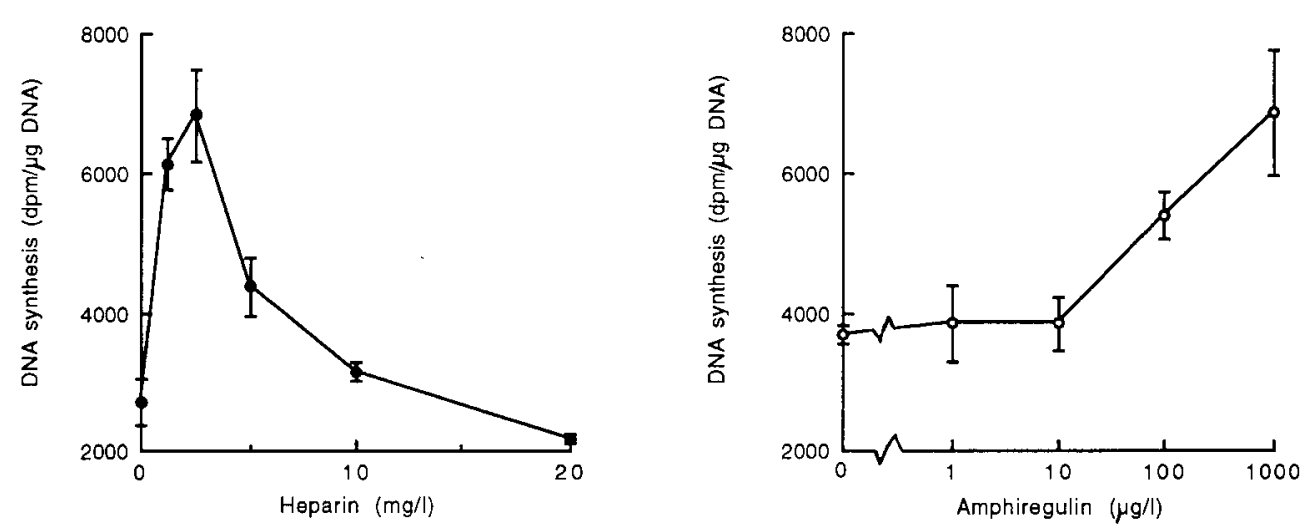

Figure 5 Effect of amphiregulin $(500 \mu \mathrm{g} / \mathrm{l})+$ hexadimethrine $(5 \mathrm{mg} / \mathrm{l})$ in the presence of increasing amounts of heparin (0-20 mg/l) on DNA synthesis (d.p.m./ $\mu \mathrm{g}$ DNA) in mammary alveolar epithelial cells from a 20-week pregnant sheep (mean \pm S.E.M. of 3 replicates). The dose-response to amphiregulin in cells from the same sheep is also shown. The experiment was repeated in cells derived from two more sheep with similar results.

\section{Discussion}

Local synthesis of growth factors plays an important role in mammary growth. Expression of both the insulin-like growth factor and epidermal growth factor families has been reported in mammary gland (see Forsyth 1996, for references) and both are mitogens for mammary epithelial cells. In ruminants, IGF-I and IGF-II are potent mitogens (Shamay et al. 1988, Baumrucker \& Stemberger 1989, Winder et al. 1989, McGrath et al. 1991, Peri et al. 1992) thought to act via the type 1 IGF receptor and stimulating a 5- to 10-fold increase in DNA synthesis. Amphiregulin and TGF- $\alpha$, members of the EGF family, approximately double DNA synthesis (Fig. 4a, Zurfluh et al. 1990, Woodward et al. 1994, Moorby et al. 1995). In primary cultures of sheep mammary gland (Moorby et al. 1995) and in the MAC-T bovine mammary epithelial cell line (Woodward et al. 1994), EGF itself is reported to be without effect. Expression of EGF is not known so far in any ruminant tissue, although EGF is an effective competitor for TGF- $\alpha$ binding to sheep mammary microsomes (Moorby et al. 1995). The mouse mammary gland expresses at least four EGF-like peptides, EGF, TGF- $\alpha$, amphiregulin and cripto-1 (Kenney et al. 1995), but their respective roles have still to be established. Multiple expression of the EGF family may also occur in ruminants, as the bovine mammary gland expresses TGF- $\alpha$ (Zurfluh et al. 1990) and the sheep amphiregulin (Forsyth et al. 1997).

Amphiregulin and TGF- $\alpha$ belong to the group of EGF agonists which bind to the EGF (ErbB-1) receptor (Shoyab et al. 1989, Cook et al. 1991, Beerli \& Hynes 1996). There are four known members of the type $1 / \mathrm{ErbB}$ family of receptor tyrosine kinases. Ligand binding induces receptor dimerization and it is now known that heterodimers as well as homodimers can be formed (Beerli \& Hynes 1996). It might have been anticipated that human recombinant amphiregulin would be a competitive inhibi- tor of TGF- $\alpha$ given its low potency on sheep mammary epithelial cells (Fig. 4a). However, the maximum response to TGF- $\alpha$ could be increased by amphiregulin. Alternative methods of intracellular signalling not shown by TGF- $\alpha$ have been proposed for amphiregulin, including interaction with defective EGF receptors lacking tyrosine kinase activity and targeting of amphiregulin to the nucleus (Cook et al. 1995b, Modrell et al. 1992). In addition, several studies now indicate that amphiregulin must associate with extracellular matrix to exhibit biological activity, a property shared with some members of the fibroblast growth factor family (Cook et al. 1995b). A part of the evidence for this has come from studying the effect of the heparin antagonist, hexadimethrine, a polymeric polycation. Hexadimethrine inhibits the mitogenic activity of amphiregulin in two mouse keratinocyte cell lines. It appears to affect the interaction between amphiregulin and cellular heparin-like glycosaminoglycans which facilitate interaction with an EGF receptor, an effect that can be overcome by equivalent concentrations of heparin (Cook et al. 1995b). Essentially similar effects of hexadimethrine have been obtained with sheep mammary epithelial cells in the present study.

Investigation of growth factors acting via the EGF receptor in ruminant mammary tissue is limited by the lack of availability of cross-reacting antibodies with antibiological activity. We have, therefore, studied the effects of soluble heparin on DNA synthesis in primary cultures of sheep mammary epithelial cells. Heparin prevents binding of amphiregulin, but not TGF- $\alpha$ or EGF, to EGF binding sites (Cook et al. 1991) and inhibits amphiregulin signalling via the human EGF receptor transfected into murine fibroblasts (Piepkorn et al. 1994). It inhibits the growth, independent of added EGF, of normal human mammary epithelial cells which express amphiregulin, an effect which can be overcome by exogenous EGF (Li et al. 1992). In these cells functional EGF receptors are necessary for 

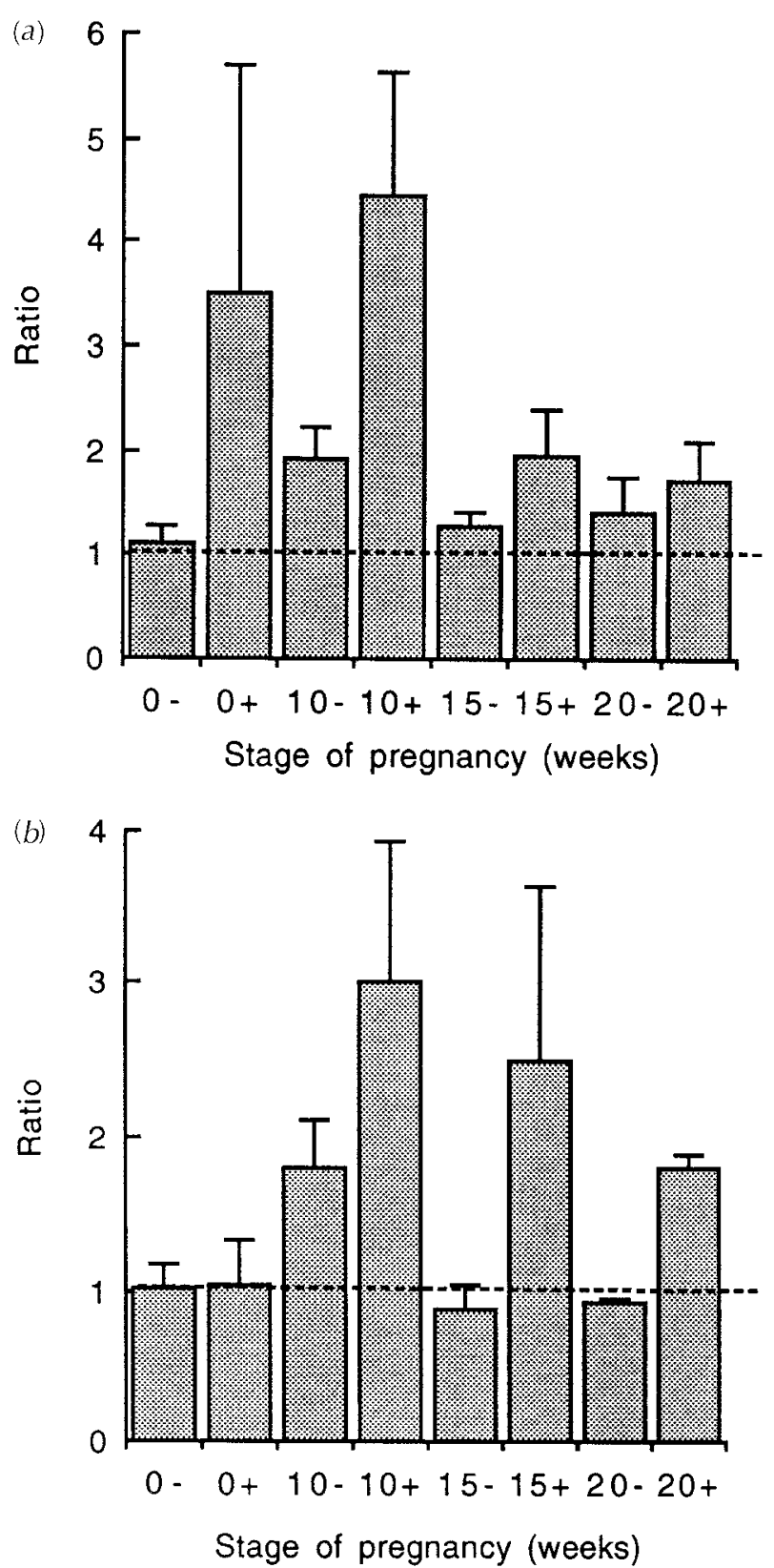

Figure 6 Interaction of effects of (a) insulin $(100 \mu \mathrm{g} / \mathrm{l})$ or $(b)$ IGF-I $(10 \mu \mathrm{g} / \mathrm{l})$ and TGF- $\alpha(10 \mu \mathrm{g} / \mathrm{l})$, on DNA synthesis measured by incorporation of $\left[{ }^{3} \mathrm{H}\right]$ methyl thymidine in cell cultures of sheep mammary alveolar epithelial cells. The vertical axis shows the ratio of (response to insulin or IGF-I in the presence of TGF- $\alpha$ ) to (response to insulin or IGF-I+response to TGF- $\alpha$ ). Cultures were carried out in the absence $(-)$ or presence $(+)$ of heparin $(10 \mathrm{mg} / \mathrm{l})$. A ratio significantly greater than 1 indicates synergism (see text). Tissues from five sheep were used at each pregnancy stage.

EGF-independent growth. Similar results have been reported for human keratinocytes (Piepkorn et al. 1994). The present study shows that DNA synthesis in sheep mammary epithelial cells is inhibited in a dose-dependent manner by heparin. The inhibition can be partially or completely reversed by TGF- $\alpha$. EGF also has an effect, although unlike the effect of TGF- $\alpha$ it does not increase with increasing dose. Moreover, the extent to which DNA synthesis is inhibited by heparin is related to the physiological state of the sheep from which the cells are derived. Although the growth of the mammary gland in pregnancy is exponential (see Fowler et al. 1990), thymidine labelling shows that proliferative activity is greatest in the first half of pregnancy (Battersby \& Anderson 1988). Inhibition of DNA synthesis by heparin was greater in cultures of mammary cells from sheep at 10-15 weeks of pregnancy than from non-pregnant or late (20-week) pregnant sheep. This might reflect the developmental changes in cell proliferation and/or changes in mammary gland amphiregulin expression. Information is limited, but Western blotting suggested amphiregulin expression may be greater in pregnant than in non-pregnant or lactating sheep (Forsyth et al. 1997).

Our previous study (Moorby et al. 1995) found that exogenous IGF-I and TGF- $\alpha$ have an additive effect on DNA synthesis by sheep mammary epithelial cells. This was established by calculating the ratio: (response to IGF-I in the presence of TGF- $\alpha$ ) to (response to IGF-I plus response to TGF- $\alpha$ ) and showing it to be not significantly different from 1. In the present study this ratio was similarly calculated to study the interaction of both insulin and IGF-I with TGF- $\alpha$ and, to take account of a possible contribution of amphiregulin, in the absence and the presence of heparin. Insulin showed a synergistic interaction with TGF- $\alpha$ which was amplified when cultures contained heparin. The additive response to IGF-I and TGF- $\alpha$ was confirmed, but this became synergistic in the presence of heparin. Blocking of endogenous amphiregulin by heparin would have the effect of reducing the denominator in the calculated ratio by removing interaction with exogenous insulin or IGF-I, a possible explanation for this result.

Confirmation of a role for endogenous amphiregulin in the growth of the normal sheep mammary gland in pregnancy will require further studies. However, together with the demonstration that amphiregulin is expressed by sheep mammary epithelial cells (Forsyth et al. 1997) and stimulates their DNA synthesis (Figs $4 a, 5$ ), the present results are consistent with such a role. The results also indicate the potential for complex interactions between the different members of the IGF and EGF growth factor families. In view of the importance of ovarian steroids in mammary growth, it is of interest that amphiregulin is oestrogen-inducible (Martinez-Lacaci et al. 1995).

\section{Acknowledgements}

This work was funded by the Biotechnology and Biological Sciences Research Council. We are grateful to David Brown for assistance with statistical analysis. 


\section{References}

Battersby S \& Anderson TJ 1988 Proliferation and secretory activity in the pregnant and lactating human breast. Virchows Archiv A. Pathology Anatomy and Histopathology 413 189-196.

Baumrucker C R \& Stemberger BH 1989 Insulin and insulin-like growth factor-I stimulate DNA synthesis in bovine mammary tissue in vitro. Journal of Animal Science 67 3503-3514.

Beerli RR \& Hynes NE 1996 Epidermal growth factor-related peptides activate distinct subsets of ErbB receptors and differ in their biological activities. Journal of Biological Chemistry 271 6071-6076.

Cook PW, Mattox PA, Keeble WW, Pittelkow MR, Plowman GD, Shoyab M, Adelman JP \& Shipley GD 1991 A heparin-sulfate regulated human keratinocyte autocrine factor is similar or identical to amphiregulin. Molecular and Cellular Biology 11 2547-2557.

Cook PW, Damm D, Garrick BL, Wood KM, Karkaria CE, Higashiyama S, Klagsbrun M \& Abraham JA 1995a Carboxyterminal truncation converts heparin-binding EGF-like growth factor (HB-EGF) from a heparin-enhancible to a heparinsuppressible growth factor. Journal of Cellular Physiology 163 407-417.

Cook PW, Ashton NM, Karkaria CE, Siess DC \& Shipley GD 1995b Differential effects of a heparin antagonist (hexadimethrine) or chlorate on amphiregulin, basic fibroblast growth factor and heparin-binding EGF-like growth factor. Journal of Cellular Physiology 163 418-429.

Forsyth IA 1996 The insulin-like growth factor and epidermal growth factor families in mammary cell growth in ruminants: action and interaction with hormones. Journal of Dairy Science 79 1085-1096.

Forsyth IA \& Moorby CD 1993 Heparin inhibition of DNA synthesis by primary cultures of sheep mammary epithelial cells. Journal of Reproduction and Fertility Abstract Series 11199.

Forsyth IA, Keable S, Taylor JA, Turvey A \& Lennard S 1997 Expression of amphiregulin in the sheep mammary gland. Molecular and Cellular Endocrinology 126 41-48.

Fowler PA, Knight CH, Cameron GG \& Foster MA 1990 In vitro studies of mammary development in the goat using magnetic resonance imaging (MRI). Journal of Reproduction and Fertility 89 $367-375$

Hinegardner RT 1971 An improved fluorometric assay for DNA. Analytical Biochemistry 39 197-201.

Johnson GR \& Wong L 1994 Heparin sulfate is essential to amphiregulin-induced mitogenic signalling by the epidermal growth factor receptor. Journal of Biological Chemistry 269 27149-27154.

Johnson GR, Saeki T, Auersperg N, Gordon AW, Shoyab M, Salomon DS \& Stromberg K 1991 Response to and expression of amphiregulin by ovarian carcinoma and normal ovarian surface epithelial cells: nuclear localization of endogenous amphiregulin. Biochemical and Biophysical Research Communications 180 481-488.

Kenney N, Johnson G, Selvam MP, Kim N, Qi C-F, Saeki T, Brandt R, Wallace-Jones B, Ciardiello F, Shoyab M, Plowman GD, Day A, Salomon DS \& Normanno N 1993 Transforming growth factor- $\alpha$ (TGF- $\alpha$ ) and amphiregulin (AR) as autocrine growth factors in non-transformed, immortalized 184AIN4 human mammary epithelial cells. Molecular and Cellular Differentiation 1 163-184.

Kenney NJ, Huang R-P, Johnson GR, Wu J-X, Okamura D, Matheny W, Kordan E, Gullick WJ, Plowman G, Smith GH, Salomon DS \& Adamson ED 1995 Detection and location of amphiregulin and Cripto-1 expression in the developing postnatal mouse mammary gland. Molecular Reproduction and Development $\mathbf{4 1}$ 277-286.

Kimura KT, Young PR, Stein RJ \& Richards RK 1959 Some pharmacological characteristics of hexadimethrine bromide (polybrene): a new antiheparin agent. Toxicology and Applied Pharmacology 1 185-202.
Li S, Plowman GD, Buckley SD \& Shipley GD 1992 Heparin inhibition of growth implicates amphiregulin as an autocrine growth factor for normal human mammary epithelial cells. Journal of Cellular Physiology 153 103-111.

McGrath MF, Collier RJ, Clemmons DR, Busby WH, Sweeny CA \& Krivi GG 1991 The direct in vitro effect of insulin-like growth factors (IGFs) on normal bovine mammary cell proliferation and production of IGF binding proteins. Endocrinology 129 671-678.

Martinez-Lacaci I, Saceda M, Plowman GD, Johnson GR, Normanno N, Salomon DS \& Dickson RB 1995 Estrogen and phorbol esters regulate amphiregulin expression in two separate human breast cancer cell lines. Endocrinology 136 3983-3992.

Modrell B, McDonald VL \& Shoyab M 1992 The interaction of amphiregulin with nuclei and putative nuclear localization sequence binding proteins. Growth Factors 7 305-314.

Moorby CD, Taylor JA \& Forsyth IA 1995 Transforming growth factor- $\alpha$ : receptor binding and action on DNA synthesis in the sheep mammary gland. Journal of Endocrinology 144 165-171.

Peri I, Shamay A, McGrath MF, Collier RJ \& Gertler A 1992 Comparative mitogenic and galactopoietic effects of IGF-I, IGF-II and des-3-IGF-I in bovine mammary gland in vitro. Cell Biology International Reports 16 359-368.

Piepkorn M, Lo C \& Plowman G 1994 Amphiregulin-dependent proliferation of cultured human keratinocytes: autocrine growth, the effects of exogenous recombinant cytokine, and apparent requirement for heparin-like glycosaminoglycans. Journal of Cellular Physiology 159 114-120.

Plowman GD, Green JM, McDonald VL, Neubauer MG, Disteche CM, Todaro GJ \& Shoyab M 1990 The amphiregulin gene encodes a novel epidermal growth factor-related protein with tumor-inhibitory activity. Molecular and Cellular Biology $\mathbf{1 0}$ 1969-1981.

Shamay A, Cohen N, Niwa M \& Gertler A 1988 Effect of IGF-I on DNA synthesis and galactopoiesis in bovine undifferentiated and lactating tissue in vitro. Endocrinology 123 804-809.

Shoyab M, McDonald VL, Bradley G \& Todaro GJ 1988 Amphiregulin: a bifunctional growth-modulating glycoprotein produced by the phorbol 12-myristate 13-acetate-treated human breast adenocarcinoma cell line MCF-7. Proceedings of the National Academy of Sciences of the USA 85 6528-6532.

Shoyab M, Plowman GD, McDonald VL, Bradley JG \& Todaro GJ 1989 Structure and function of amphiregulin: a member of the epidermal growth factor family. Science 243 1074-1076.

Thorne B \& Plowman GD 1994 The heparin-binding domain of amphiregulin necessitates the precursor pro-region for growth factor secretion. Molecular Reproduction and Development 14 1635-1686.

Winder SJ, Turvey A \& Forsyth IA 1989 Stimulation of DNA synthesis in cultures of ovine mammary epithelial cells by insulin and insulin-like growth factors. Journal of Endocrinology 123 319-326.

Winder SJ, Turvey A \& Forsyth IA 1992 Characteristics of ruminant mammary epithelial cells grown in primary culture in serum-free medium. Journal of Dairy Research 59 491-498.

Woodward TL, Akers RM \& Turner JD 1994 Lack of mitogenic response to EGF, pituitary and ovarian hormones in bovine mammary epithelial cells. Endocrine 2 529-535.

Zurfluh LL, Bolten SL, Byatt JC, McGrath MF, Tou JS, Zupec ME \& Krivi GG 1990 Isolation of genomic sequence encoding a biologically active bovine TGF- $\alpha$ protein. Growth Factors 3 257-266.

Received 12 May 1997

Revised manuscript received 20 August 1997

Accepted 18 September 1997 